\title{
Butyltins, Organochlorines and Metal Levels in Green Mussel, Perna viridis L. from the Coastal Waters of the Philippines
}

\author{
Maricar Prudente, ${ }^{* 1}$ Hideki Ichihashi, ${ }^{* 2}$ Supawat Kan-atireklap, ${ }^{* 3}$ \\ Izumi Watanabe, ${ }^{* 3, \uparrow 1}$ and Shinsuke Tanabe ${ }^{* 3, \uparrow 2}$ \\ ${ }^{*}$ Science Education Department, De La Salle University, 2401 Taft Avenue, Manila, \\ 1004 Philippines \\ ${ }^{*}{ }_{2}$ The Institute of Cetacean Research, Toyomi, Chuo, Tokyo 104-0055, Japan \\ ${ }^{*}$ Department of Environment Conservation, Ehime University, \\ Tarumi, Matsuyama 790-8566, Japan
}

(Received December 14, 1998)

\begin{abstract}
Contamination by butyltins (BTs), organochlorine compounds (OCs) and heavy metals was examined in green mussels collected along the coastal areas of the Philippines in 1994 and 1997. Significant BTs concentrations revealed widespread contamination along nearshore marine waters. Relatively high BTs concentrations were observed in samples collected from areas with high boating activities, suggestive that the source of TBT (tributyltin) is coming from antifouling paints. While TBT levels were found to be low in green mussels collected from aquaculture areas, implying minimal usage of BTs for aquaculture activities. The composition of BT derivatives in mussel was in the order of TBT $>$ DBT $>$ MBT, reflective of continuous input of TBT in the coastal waters. Considering the unregulated use of organotins in the country, BTs contamination in the aquatic environment of the Philippines may increase in the future. Concentrations of OCs in green mussels were less than BTs. Among OCs, PCBs concentrations were found to be relatively high particularly in mussels from Manila Bay. Moreover, metal concentrations found suggest that the anthropogenic loading of $\mathrm{Hg}, \mathrm{Pb}$ and $\mathrm{Cd}$ to the coasts is relatively low, suggestive that the green mussels from these coastal waters are not adversely affected by these metal toxicants and pose no risk for human health. To our knowledge, this is the first comprehensive report on the concentrations of butyltins, organochlorine compounds and heavy metals in soft tissues of green mussels in the Philippines.
\end{abstract}

Key words: butyltins, organochlorines, green mussel, heavy metals, coastal waters, Philippines

Mussels of the genus Perna are in many respects highly suitable for culture in the coastal areas. Being filter feeders, they occupy a low position in the food chain, making their exploitation a very economic utilization of the primary production available in coastal waters. Moreover, mussels have a high protein content, averaging $67 \%$ of its body weight, ${ }^{1)}$ which compares favorably with other food items and underscores its importance as a source of inexpensive animal protein. It is for these reasons that mussels have become one of the most valuable mariculture organisms produced in Asia with the largest quantity. ${ }^{2}$ In particular, the green mussel Perna viridis, which has a wide geographical distribution in the Asia-Pacific region, is recognized as a commercially valuable seafood. ${ }^{3}$ The Philippines is one of those countries that have ventured into large-scale exploitation of the green mussel Perna viridis. As early as the 1950's, the Philippines was one of the countries outside Europe to have explored the possibilities of intensive mussel culture. In 1955, the first commercial mussel farm started operation, marking the beginning of a mussel industry that has proved to be as lucrative as the oyster industry. ${ }^{4,5)}$
Presently, the major mussel culture areas in the Philippines include Sapian Bay (Capiz), Maqueda Bay (Jiabong, Samar), and Bacoor Bay (Cavite) ${ }^{6}{ }^{6}$ Nevertheless, despite the fact that mussels are part of the nation's diet, monitoring studies on the residues of toxic contaminants in this seafood is rather limited. Cognizant of possible implications on public health and safety, it was deemed necessary to conduct the present study in order to assess the levels of toxic contaminants such as butyltins (BTs), organochlorine compounds (OCs) and heavy metals in green mussels collected from Philippines' coastal waters, particularly in the major mussel culture areas. Moreover, the present study is a part of the Asia-Pacific Mussel Watch Program, which aims to monitor marine pollution in this region using mussel as bioindicator.")

Rapid increase of chemical trade in Asian developing countries such as the Philippines implies greater production and usage of toxic chemicals that could lead to increase exposure of humans and wildlife to these chemicals. Consequently, environmental problems associated with toxic contaminants such as BTs, OCs and heavy metals are

\footnotetext{
${ }^{\dagger}$ Present address: Department of Environmental Conservation, Tokyo University of Agriculture and Technology, Saiwai-cho, Fuchu 183-8509, Japan.

t2 To whom correspondence should be addressed.
} 
of great concern. BTs representing tributyltin (TBT) were used widely for pleasure boats, large ships and vessels, docks and fishing nets, lumber preservatives and slimicides in cooling systems, and as an effective antifouling agent in paints. Its derivatives dibutytin (DBT) and monobutyltin (MBT) were mostly used as stabilizers in polyvinyl chloride and as catalysts in the production of polyurethane foams, silicones, and in other industrial processes. ${ }^{8)}$ Aquatic pollution by TBT coming from antifouling paints has been of great concern in many countries due to their reported effects on non-target marine organisms, i.e. shell malformation in oysters, ${ }^{9,10)}$ mortality on the larvae of mussels, ${ }^{11)}$ and imposex in gastropods. ${ }^{12)}$ These findings led to the restriction of TBT-based antifouling paints in most developed nations, however, in most developing countries including the Philippines, such control is yet to be enforced. Moreover, an increasing demand for antifouling paints is predicted in the Asia-Pacific, ${ }^{13)}$ anticipating aquatic pollution and toxic biological effects by BTs in this region. On the other hand, persistent OCs such as PCBs (polychlorinated biphenyls), DDTs, HCHs (hexachlorocyclohexane isomers), CHLs (chlordane compounds), and HCB (hexachlorodenzene) have been recently reported to show estrogenic properties, ${ }^{14)}$ in addition to the well-documented environmental problems and human health hazards that these toxic compounds have caused. Although most developed nations have banned or restricted the production and use of these compounds during the last decade, developing countries still use these chemicals for agricultural and public health purposes. In the Philippines, use of OCs for agricultural purposes were halted in $1977^{15}$ and usage of DDTs for malaria control was phased-out in $1992 .{ }^{16}$ Meanwhile, heavy metals in trace concentrations are normal constituents of marine organisms. But at high levels, they are potentially toxic and may disrupt the biological activities of aquatic ecosystems. The ability of heavy metals to be concentrated in the organs of marine organisms accounts for their toxicity and also poses a direct threat to both the aquatic biota and man. ${ }^{17)}$ Studies on the Philippine environment conducted by our team have shown the presence of these contaminants in the different environmental compartments such as heavy metals in sediments ${ }^{18)}$ and fish, ${ }^{19)}$ OCs in soils, sediments, ${ }^{20)}$ and cetaceans, ${ }^{21)}$ and BTs in cetaceans. ${ }^{22}$

The present study aims to assess the levels of contamination by BTs, OCs and heavy metals using green mussel Perna viridis as a bioindicator of marine pollution. Concentrations of TBT, DBT and MBT in the whole soft tissue of green mussels collected along the coastal areas of the Philippines were determined. OCs residues such as PCBs, DDTs, HCHs, CHLs, and HCB were also examined. In addition, analyses of 13 elements $(\mathrm{Li}, \mathrm{V}, \mathrm{Mn}, \mathrm{Co}, \mathrm{Cu}, \mathrm{Zn}$, $\mathrm{Rb}, \mathrm{Sr}, \mathrm{Ag}, \mathrm{Cd}, \mathrm{Cs}, \mathrm{Pb}$ and $\mathrm{Hg}$ ) are presented here and their concentrations in the whole soft tissue of these green mussels are discussed. Moreover, in order to determine the degree of marine pollution in these coastal waters, concentrations detected in this study were compared with reported values from other regions.

\section{Materials and Methods}

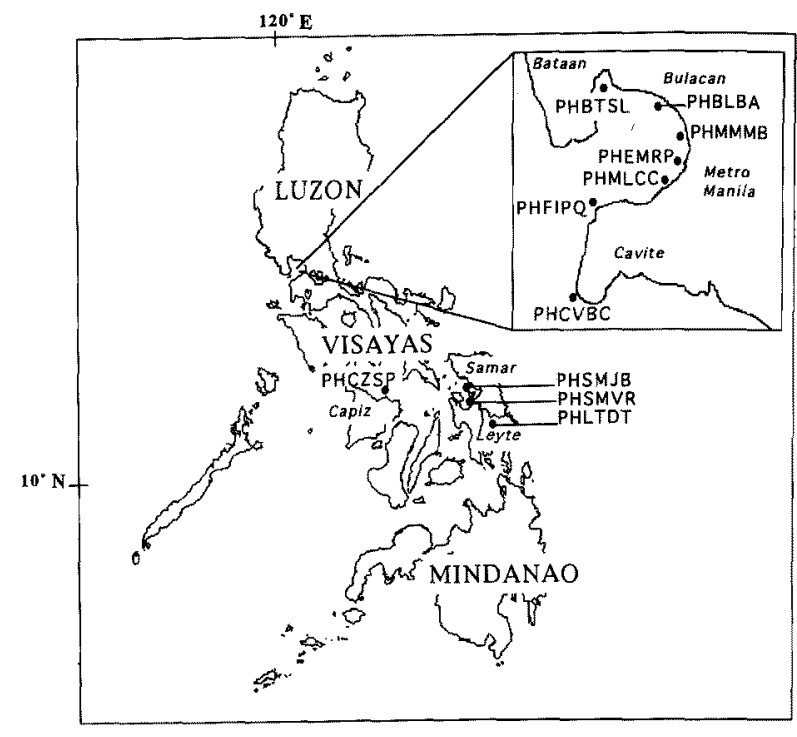

Fig. 1. Sampling locations of green mussels used in the study.

Green mussels Perna viridis were collected from various coastal sites in the Philippines (Fig. 1). Samples collected from 5 sites in 1994 and from 8 sites in 1997 were used for BTs and OCs analyses (Table 1), while mussel samples collected in 1997 were employed for the analyses of the 14 elements (Table 2). More than 100 green mussels were collected from each location and the adhering matrix was removed in the field. Samples were stored in polyethylene bags, kept in a cooler box with ice or dry ice and then immediately kept in a deep-freezer. The frozen mussels were subsequently transported to the laboratory in Japan, thawed, scraped clean and shucked. For BTs and OCs analyses, the whole soft tissues were pooled, homogenized, then kept in clean glass bottles, and the mussels for metal analyses were kept in clean polyethylene bags. All samples were frozen at $-20^{\circ} \mathrm{C}$ until chemical analysis.

\section{Chemical Analyses}

$B T$ s. The analytical method of BTs was conducted based on the procedure previously described. ${ }^{23)}$ The method consists of extraction, propylation, purification and quantification by Hewlett-Packard 5890 Series II gas chromatograph equipped with a flame photometric detector (GC-FPD). For quantification of BTs, a fused silica capillary column (J\&W Scientific Co. Ltd., $30 \mathrm{~m}$ length $\times 0.25 \mathrm{~mm}$ id., 0.25 $\mu \mathrm{m}$ film thickness) coated with DB-1 ( $100 \%$ dimethyl polysiloxane) was used. Recoveries of BTs from the spiked mussel tissues were $87 \pm 14 \%, 137 \pm 20 \%$ and $107 \pm 25 \%$ for MBT, DBT and TBT $(n=7)$, respectively. The detection limit was $3 \mathrm{ng} \mathrm{g}^{-1}$ for MBT and $1 \mathrm{ng} \mathrm{g}^{-1}$ for DBT and TBT.

OCs. PCBs and organochlorine pesticides were determined based on the analytical method described earlier. ${ }^{23)}$ The method consists of extraction, fat removal, acid treatment, fractionation and quantification. Hewlett-Packard 5890 Series II gas chromatograph equipped with ${ }^{63} \mathrm{Ni}$ electron capture detector (GC-ECD) and a moving needle type injection system with splitless and solvent-cut mode was used for the determination of OCs. PCBs was quantified 
Table 1. Locations and biological details of green mussel Perna viridis employed for BTs and OCs analyses

\begin{tabular}{|c|c|c|c|c|c|c|}
\hline Location & Site code ${ }^{* 1}$ & Date $^{* 2}$ & $n$ & Shell length (mm) & Soft tissue weight $(g)$ & Fat content $(\%)$ \\
\hline Freedom Island, Paranaque, Metro Manila & PHFIPQ & 941122 & 32 & $40(35-50)$ & $1.2(0.8-2.1)$ & 3.1 \\
\hline Rizal Park, Ermita, Manila & PHEMRP & 941125 & 19 & $47(40-57)$ & $3.0(1.6-5.8)$ & 2.0 \\
\hline CCP Complex, Malate, Manila & PHMLCC & 941127 & 32 & $54(48-63)$ & $2.5(1.3-4.3)$ & 1.6 \\
\hline Bocaue, Bulacan & PHBLBA-1 & 941128 & 41 & $65(51-80)$ & $4.1(1.9-8.4)$ & 1.5 \\
\hline Bocaue, Bulacan & PHBLBA-2 & 970411 & 29 & $66(57-80)$ & $8.3(4.9-13.8)$ & 1.8 \\
\hline Bacoor, Cavite & PHCVBC-1 & 941130 & 39 & $63(54-80)$ & $3.6(2.1-6.3)$ & 1.2 \\
\hline Bacoor, Cavite & PHCVBC-2 & 970409 & 30 & $77(63-109)$ & $11.5(7.1-25.6)$ & 1.8 \\
\hline Jiabong, Samar & PHSMJB & 970404 & 30 & $77(48-100)$ & $7.4(1.6-11.3)$ & 1.5 \\
\hline Villareal, Samar & PHSMVR & 970405 & 30 & $76(63-86)$ & $8.2(5.9-11.0)$ & 1.8 \\
\hline Diit, Leyte & PHLTDT & 970406 & 30 & $78(62-114)$ & $5.3(1.8-14.4)$ & 0.5 \\
\hline Sapian Bay, Capiz & PHCZSP & 970407 & 18 & $76(69-87)$ & $5.1(4.0-6.6)$ & 1.2 \\
\hline Samal, Bataan & PHBTSL & 970408 & 51 & $46(35-53)$ & $3.1(2.0-5.4)$ & 1.7 \\
\hline Malabon, Metro Manila & PHMMMB & 970410 & 30 & $68(58-80)$ & $9.6(5.2-15.6)$ & 2.6 \\
\hline
\end{tabular}

*1 First, second and third letters indicate the country, province or city and local name, respectively; digits indicate replicate time of sampling

*2 $_{2}$ First, second and last two digits indicate the year, month and date respectively.

$n$ : number of pooled samples.

Values in parentheses indicate range.

Table 2. Biological details of green mussels Perna viridis employed for heavy metal analyses

\begin{tabular}{|c|c|c|c|c|c|c|}
\hline Location & Site $\operatorname{code}^{* 1}$ & Date*2 & $n$ & Shell length $(\mathrm{mm})$ & Soft tissue weight (g) & Moisture \% \\
\hline Jiabong, Samar & PHSMJB & 970404 & 20 & $8.21(7.60-9.10)$ & $8.65(7.30-9.71)$ & $82.0(80.2-83.9)$ \\
\hline Villareal, Samar & PHSMVR & 970405 & 20 & $7.79(7.10-8.70)$ & $8.36(6.50-10.3)$ & $78.9(78.3-79.5)$ \\
\hline Dit, Leyte & PHLTDT & 970406 & 20 & $8.05(7.30-8.80)$ & $4.79(2.42-8.06)$ & $85.8(84.7-87.6)$ \\
\hline Sapian Bay, Capiz & PHCZSP & 970407 & 20 & $7.50(6.90-8.50)$ & $4.41(3.47-5.77)$ & $84.7(82.5-86.3)$ \\
\hline Samal, Bataan & PHBTSL & 970408 & 20 & $4.45(3.80-5.10)$ & $2.39(1.94-3.09)$ & $81.3(79.6-83.4)$ \\
\hline Bacoor, Cavite & PHCVBC-2 & 970409 & 20 & $6.58(6.10-6.90)$ & $6.90(5.22-8.76)$ & $78.1(76.2-79.8)$ \\
\hline Malabon, Metro Manila & PHMMMB & 970410 & 20 & $7.14(6.30-8.50)$ & $8.01(5.02-12.4)$ & $77.5(76.6-77.9)$ \\
\hline Bocaue, Bulacan & PHBLBA-2 & 970411 & 20 & $7.08(6.30-7.90)$ & $9.12(7.91-11.6)$ & $80.9(79.4-82.9)$ \\
\hline
\end{tabular}

* First, second and third letters indicate the country, province or city and local name, respectively. The digits indicate replicate time of sampling.

$*_{2}$ First, second and last two digits indicate the year, month, and date respectively.

$n$ : no. of pooled samples.

Values in parentheses indicate the range.

by a fused-silica capillary column $(30 \mathrm{~m}$ length $\times 0.25 \mathrm{~mm}$ id., $0.25 \mu \mathrm{m}$ film thickness) coated with SE-54 (Supelco Inc., PA, USA). Quantification of OCs pesticides was performed on a column which consisted of fused silica capillary (30 m length $\times 0.25 \mathrm{~mm}$ id., $0.25 \mu \mathrm{m}$ film thickness) coated with DB-1 (J\&W Scientific Co. Ltd.). Total PCB concentrations in samples were quantified by summing the concentrations of individually resolved peaks relative to an equivalent mixture standard of Aroclor (1016:1242:1254:1260; 1:1:1:1) with known PCB composition and content. ${ }^{24)}$ Recoveries of OCs residues by this method with fortified samples were $106 \pm 2 \%$ for PCBs, $108 \pm 6 \%$ for CHLs, $105 \pm 10 \%$ for $\mathrm{HCHs}$ and $105 \pm 3 \%$ for HCB $(n=4)$, respectively. The detection limit was 0.1 $\mathrm{ng} \mathrm{g}^{-1}$ for PCBs and $0.01 \mathrm{ng} \mathrm{g}^{-1}$ for $\mathrm{OC}$ pesticides.

Metals. Elemental analyses were carried out by inductively coupled plasma-mass spectrometry (ICP-MS) (Perkin Elmar 5000) after microwave digestion with nitric acid in a PTFE (teflon) vessel. ${ }^{25)}$ The reference material NIST SRM 15776 bovine liver was used to calculate metal recoveries. Total $\mathrm{Hg}$ was determined by cold vapor technique, using a Sansou Automatic Mercury Analyzer Model HG-3000. ${ }^{26}$ Concentrations of all elements are reported as $\mu \mathrm{g} \mathrm{g}^{-1}$ on a dry weight basis.

\section{Results and Discussion}

\section{Butyltin Compounds}

Among BTs, TBT was detected in most of the sampling sites at relatively high concentrations, whereas the concentrations of DBT and MBT were lower (Table 3). Concentrations of BTs in green mussels from the Philippines ranged from $<3$ to $51 \mathrm{ng} \mathrm{g}^{-1}$ for MBT, $<1$ to $100 \mathrm{ng} \mathrm{g}^{-1}$ for DBT and $<1$ to $640 \mathrm{ng} \mathrm{g}^{-1}$ for TBT. Relatively high TBT concentrations were observed in samples collected from areas with high boating activities. The concentrations of $\Sigma \mathrm{BT}$ (MBT + DBT + TBT) in mussels from boating areas around Manila Bay (PHEMRP: $787 \mathrm{ng} \mathrm{g}^{-1}$, PHMLCC: $294 \mathrm{ng} \mathrm{g}^{-1}$, PHFIPQ: $104 \mathrm{ng} \mathrm{g}^{-1}$ ) suggest that the source of TBT was coming from antifouling paints. A number of studies have documented the existence of TBT contamination in harbours, marinas, shipyard hull washing/refinishing and boating activities. ${ }^{27-29)}$ On the other hand, $\Sigma$ BT levels were found to be low in green mussels collected from aquaculture areas (PHSMJB: $4 \mathrm{ng} \mathrm{g}^{-1}$, PHLTDT: $<1 \mathrm{ng} \mathrm{g}^{-1}$, PHCZSP: $1 \mathrm{ng} \mathrm{g}^{-1}$ and PHBTSL: $<1 \mathrm{ng} \mathrm{g}^{-1}$ ), implying minimal usage of BTs for aquaculture activities in the Philippines. Considerably low levels of BTs were also noted in aquaculture areas located upward of the Manila bay area (PHBLBA-1: $22 \mathrm{ng} \mathrm{g}^{-1}$, PHBLBA- 
Table 3. Concentrations (ng $g^{-1}$ wet weight) of butyltin compounds (BTs) and organochlorine (OCs) residues in green mussel $P$ Perna viridis collected from Philippine coastal waters

\begin{tabular}{|c|c|c|c|c|c|c|c|c|c|}
\hline Site code & $\mathrm{MBT}$ & DBT & TBT & $\Sigma B T$ & PCBs & DDTs & CHLS & $\mathrm{HCHs}$ & $\mathrm{HCB}$ \\
\hline PHFIPQ & 15 & 13 & 76 & 104 & 36 & 3.3 & 9.5 & 0.19 & 0.04 \\
\hline PHEMRP & 47 & 100 & 640 & 787 & 32 & 4.2 & 7.2 & 0.11 & 0.02 \\
\hline PHMLCC & 51 & 43 & 200 & 294 & 33 & 3.2 & 7.4 & 0.09 & 0.02 \\
\hline PHBLBA-1 & 5 & 4 & 13 & 22 & 8.7 & 1.3 & 2.9 & 0.13 & 0.02 \\
\hline PHBLBA-2 & $<3$ & 12 & 34 & 46 & 22 & 1.7 & 2.5 & 0.15 & 0.01 \\
\hline PHCVBC-1 & 9 & 8 & 34 & 51 & 22 & 1.6 & 2.4 & 0.09 & 0.02 \\
\hline PHCVBC-2 & $<3$ & 16 & 43 & 59 & 14 & 1.1 & 3.6 & 0.13 & $<0.01$ \\
\hline PHSMJB & $<3$ & 3 & 1 & 4 & 0.7 & 1.3 & 0.19 & $<0.01$ & 0.01 \\
\hline PHSMVR & $<3$ & 2 & 28 & 30 & 2.3 & 0.8 & 0.36 & 0.06 & 0.01 \\
\hline PHLTDT & $<3$ & $<1$ & $<1$ & $<1$ & 1.1 & 0.2 & 0.15 & $<0.01$ & 0.01 \\
\hline PHCZSP & $<3$ & 1 & $<1$ & 1 & 0.9 & 0.3 & 0.22 & 0.08 & 0.02 \\
\hline PHBTSL & $<3$ & $<1$ & $<1$ & $<1$ & 2.6 & 1.6 & 0.34 & 0.16 & 0.01 \\
\hline PHMMMB & 3 & 15 & 44 & 62 & 31 & 2.0 & 3.2 & 0.13 & 0.01 \\
\hline
\end{tabular}

$\Sigma \mathrm{BT}=\mathrm{MBT}+\mathrm{DBT}+\mathrm{TBT}$

Table 4. Concentrations (ng $\mathrm{g}^{-1}$ wet weight) of butyltin compounds and organochlorine residues in bivalve molluscs collected worldwide

\begin{tabular}{|c|c|c|c|c|c|c|c|c|c|c|}
\hline Organism & Location & MBT & DBT & TBT & $\mathrm{PCBs}$ & DDTs & CHLs & $\mathrm{HCHs}$ & $\mathrm{HCB}$ & References \\
\hline \multirow{5}{*}{$\begin{array}{l}\text { Mytulis } \\
\text { edulis }\end{array}$} & Tokyo Bay, Japan (1989) & $20-120$ & $40-450$ & $20-240$ & - & - & - & - & - & Higashiyama et al., 1991 \\
\hline & East Coast, USA & ND-140 & $10-580$ & $10-1200$ & - & - & - & - & - & Uhler et al., 1993 \\
\hline & Perth, Australia (1991) & NA & NA & $<1-330$ & $<10$ & $<1-2$ & - & - & - & Burt and Ebell, 1995 \\
\hline & Kattegat, Denmark (1985) & - & - & - & $3-328$ & $2.4-67$ & - & $0.6-7.4$ & - & Granby and Spliid, 1995 \\
\hline & SW Baltic Sea (1990-1991) & - & - & - & $4.7-97$ & $<1-18$ & - & $0.3-4.5$ & ND-1 & Lee et al., 1996 \\
\hline \multirow{8}{*}{$\begin{array}{l}\text { Perna } \\
\text { viridis }\end{array}$} & Hong Kong (1986) & - & - & - & $49-330$ & $50-520$ & - & $53-100$ & - & Phillips, 1989 \\
\hline & Hong Kong (1989) & NA & NA & $64-115$ & - & - & - & - & - & Chiu et al., 1991 \\
\hline & Thailand (1994) & $<3-45$ & $<2-66$ & $5-200$ & $0.17-12$ & $1.3-38$ & $0.3-5.9$ & $<0.01-0.22$ & $<0.01-0.09$ & Kan-atireklap et al.1997 \\
\hline & Thailand (1995) & $<3-42$ & $<2-80$ & $3-680$ & $<0.01-20$ & $1.3-15$ & $0.25-3.5$ & $<0.01-0.43$ & $<0.01-0.12$ & Kan-atireklap et al., 1997 \\
\hline & India (1994-1995) & $<3-45$ & $<1-110$ & $<1-640$ & $0.31-15$ & $0.93-40$ & $<0.01-1.9$ & $1.5-12$ & $<0.01-0.38$ & Kan-atireklap et al., 1997 \\
\hline & Malaysia (1992) & $\mathrm{NA}$ & $\mathrm{NA}$ & $14.2-23.5$ & - & - & - & - & - & Tong et al., 1996 \\
\hline & South India (1988-1989) & - & - & - & $0.66-7.1$ & $2.8-40$ & - & $4.3-16$ & - & Ramesh et al., 1990 \\
\hline & Philippines (1994-1997) & $<3-51$ & $<1-100$ & $<1-640$ & $0.69-36$ & $0.19-4.2$ & $0.15-9.5$ & $<0.01-0.19$ & $<0.01-0.04$ & This Study \\
\hline
\end{tabular}

2: $46 \mathrm{ng} \mathrm{g}^{-1}, \mathrm{PHMMB}-62 \mathrm{ng} \mathrm{g}^{-1}$ ). Thus, it is probable that the major BTs pollution sources in the country are far sea or commercial vessels that could be using TBT-coated antifouling agents on the ship hulls. Though the exact pollution source of BTs remains uncertain, present findings indicate that BTs contamination seems to be widespread along Philippine's coastal waters. TBT levels $\left(<1\right.$ to $\left.640 \mathrm{ng} \mathrm{g}^{-1}\right)$ found in mussel samples from Philippine waters were comparable with those in Thailand, but were higher than those in other Asian countries such as Malaysia and Hong Kong (Table 4). Similar to Thailand, ${ }^{23)}$ pollution of BTs in the Philippines may be considered to be high among Asian developing countries so far reported. However, when compared with recent surveys of other bivalve species from various locations, BTs levels in Philippines were lower than those in developed nations (Table 4).

The compositional ratio of butyltin derivatives in $P$. viridis analysed here was observed to be in the order of TBT $>$ DBT $>$ MBT. Among BTs, TBT was the dominant compound occupying about $70 \%$ in most locations, while DBT and MBT comprised less than $30 \%$. Present findings conform with the observations made by Kan-atireklap et al. ${ }^{23)}$ on the limited ability of $P$. viridis to metabolize TBT to DBT and MBT similar to other molluses. Such limitation was explained by the low cytochrome P-450 content and mixed function oxygenase activity in molluscs. ${ }^{30,31)}$ Additionally, continuous input of TBT in the coastal waters of the Philippines may also provide a plausible explanation for the higher ratio of TBT found in mussel samples analysed.

\section{Organochlorine Compounds}

Concentrations of PCBs in $P$. viridis from the coastal waters of the Philippines ranged from 8.7 to $36 \mathrm{ng} \mathrm{g}^{-1}$ in 1994 and 0.7 to $31 \mathrm{ng} \mathrm{g}^{-1}$ in 1997 (Table 3). Among the various sites, relatively higher PCBs levels were measured in green mussels collected around Manila Bay area (PHFIPQ: $36 \mathrm{ng} \mathrm{g}^{-1}$, PHMLCC: $35 \mathrm{ng} \mathrm{g}^{-1}$, PHEMRP: $32 \mathrm{ng} \mathrm{g}^{-1}$, and PHMMMB: $31 \mathrm{ng} \mathrm{g}^{-1}$ ) (Table 3). These levels may imply that PCBs contamination could be coming from the more populated and industrialized cities. Based on international comparison of PCB levels reported in bivalve molluscs (Table 4), values found in the present study were similar to that in Thailand mussels, but slightly higher than those found in mussels from South India. However, PCB levels in mussels from Philippines were found to be lower than those detected in mussels from Hong Kong, Denmark and the South West Baltic Sea (Table 4). Although contamination by PCBs in Philippine coastal waters may not be serious at present, continuous 
Table 5. Metal concentrations ( $\mu \mathrm{g} \mathrm{g}^{-1}$ dry weight) in green mussels Perna viridis collected from Philippine coastal waters

\begin{tabular}{|c|c|c|c|c|c|c|c|c|c|c|c|c|c|c|}
\hline Region & Site Code & $\mathrm{Li}$ & $\mathrm{V}$ & $\mathrm{Mn}$ & $\mathrm{Co}$ & $\mathrm{Cu}$ & $\mathrm{Zn}$ & $\mathrm{Rb}$ & $\mathrm{Sr}$ & $\mathrm{Ag}$ & $\mathrm{Cd}$ & $\mathrm{Cs}$ & $\mathrm{Hg}$ & $\mathrm{Pb}$ \\
\hline \multicolumn{15}{|l|}{ Luzon } \\
\hline & PHBTSL & 1.14 & 3.16 & 90.7 & 0.77 & 8.85 & 40.2 & 3.85 & 23.6 & 0.014 & 0.296 & 0.059 & 0.261 & 0.280 \\
\hline & PHBLBA-2 & 1.62 & 0.48 & 107 & 0.24 & 5.82 & 38.4 & 3.57 & 25.8 & 0.044 & 0.074 & 0.010 & 0.561 & 0.082 \\
\hline & PHMMMB & 4.16 & 0.54 & 33.7 & 0.43 & 5.13 & 42.5 & 4.57 & 20.9 & 0.102 & 0.148 & 0.013 & 0.252 & 0.130 \\
\hline & PHCVBC-2 & 9.90 & 0.86 & 27.4 & 0.39 & 5.73 & 44.4 & 3.75 & 28.5 & 0.232 & 0.152 & 0.010 & 0.131 & 0.111 \\
\hline \multicolumn{15}{|l|}{ Visayas } \\
\hline & PHCZSP & 1.75 & 3.75 & 95.0 & 1.10 & 5.91 & 51.6 & 2.27 & 77.0 & 0.009 & 0.351 & 0.031 & 0.680 & 0.243 \\
\hline & PHSMJB & 2.01 & 2.88 & 112 & 0.97 & 6.41 & 45.4 & 3.40 & 53.7 & 0.010 & 0.960 & 0.030 & 0.138 & 0.186 \\
\hline & PHSMVR & 4.88 & 0.77 & 33.8 & 2.16 & 6.02 & 44.8 & 3.55 & 19.0 & 0.015 & 0.761 & 0.017 & 0.197 & 0.105 \\
\hline & PHLTDT & 1.90 & 2.80 & 88.5 & 0.84 & 5.38 & 57.2 & 2.49 & 71.7 & 0.018 & 0.468 & 0.021 & 0.522 & 0.205 \\
\hline \multirow[t]{2}{*}{ NIST SRM } & Values found & 0.178 & 0.113 & 9.58 & 0.231 & 164 & 126 & 12.8 & 0.139 & 0.043 & 0.50 & 0.013 & NA & 0.137 \\
\hline & Certified values & - & 0.123 & 10.5 & 0.250 & 160 & 127 & 13.7 & 0.136 & 0.039 & 0.50 & - & - & 0.129 \\
\hline
\end{tabular}

NA: Not analysed.

monitoring in industrialized and highly populated locations such as around Manila Bay (PHFIPQ, PHMLCC, PHEMRP and PHMMMB) and Bacoor Bay (PHCVBC) is apparently needed.

Among various OCs pesticides determined in the present study, CHLs concentrations were the highest in 8 out of 13 samples examined (Table 3 ). CHLs concentrations in green mussels from Philippines' coastal waters were detected in the range of 2.4 to $9.5 \mathrm{ng} \mathrm{g}^{-1}$ in 1994 and 0.15 to $3.6 \mathrm{ng} \mathrm{g}^{-1}$ in 1997. CHLs levels in green mussels collected from coastal waters proximal to urbanized and industrialized areas (PHFIPQ: $9.5 \mathrm{ng} \mathrm{g}^{-1}$, PHMLCC: 7.4 ng g ${ }^{-1}$, PHEMRP: $7.2 \mathrm{ng} \mathrm{g}^{-1}$, PHMMMB: $3.2 \mathrm{ng} \mathrm{g}^{-1}$ and PHCVBC: $2.4-3.6 \mathrm{ng} \mathrm{g}^{-1}$ ) were one magnitude higher than those from the coasts of rural areas (PHSMJB: 0.19 ng g ${ }^{-1}$, PHSMVR: $0.36 \mathrm{ng} \mathrm{g}^{-1}$, PHLTDT: $0.15 \mathrm{ng} \mathrm{g}^{-1}$, PHCZSP: $\quad 0.22 \mathrm{ng} \mathrm{g}^{-1}$ and PHBTSL: $0.34 \mathrm{ng} \mathrm{g}^{-1}$ ) (Table 3). This spatial distribution found in Philippines is suggestive that CHL might be used partly against termites in the more populated areas, similar to Japan. On an international basis, monitoring data on CHLs residues in bivalves is rather scarce. Nevertheless, comparable levels of CHLs $\left(0.25-5.9 \mathrm{ng} \mathrm{g}^{-1}\right)$ were found in $P$. viridis from Thailand's coastal waters (Table 4).

DDTs were detected at levels next to CHLs, ranging from 1.3 to $4.2 \mathrm{ng} \mathrm{g}^{-1}$ in 1994 and 0.2 to $2.0 \mathrm{ng} \mathrm{g}^{-1}$ in 1997. This finding may be reflective of the past usage of DDT for malaria control in the Philippines until it was officially halted in $1992 .{ }^{16)}$ Compared with other studies, DDT concentrations obtained for green mussels in the Philippines were lower than those found in mussels from Hong Kong by about 2 orders of magnitude, and those from Thailand, South India, and Denmark by about 1 order of magnitude. While DDT levels obtained here were within the same range as the levels found in blue mussels from Perth, Australia and the South West Baltic Sea (Table 4).

Concentrations of $\mathrm{HCHs}$ detected here were rather uniform among the sampling sites and were relatively low, ranging from 0.09 to $0.19 \mathrm{ng} \mathrm{g}^{-1}$ in 1994 and $<0.01$ to $0.16 \mathrm{ng} \mathrm{g}^{-1}$ in 1997. Similar to CHLs, HCHs levels in green mussels from the Philippines were within the same range as those from Thailand's coasts, but were found to be much lower than those from other aquatic regions (Table 4).

HCB concentrations were the lowest, ranging from 0.02 to $0.04 \mathrm{ng} \mathrm{g}^{-1}$ and $<0.01$ to $0.02 \mathrm{ng} \mathrm{g}^{-1}$ in 1997. The uniform $\mathrm{HCB}$ concentrations found in green mussels from the various study sites were within the same range as the levels detected in green mussels from the coastal waters of Thailand (Table 4). It has been reported that $\mathrm{HCB}$ contamination may have originated from usage of fungicides or as an impurity in pesticide formulations, a byproduct of various chlorination processes, and the combustion of industrial and municipal wastes. ${ }^{32)}$

Collectively, OC residues in Perna viridis from Philippine coastal waters were suggestive that organochlorines have been widely used in the Philippines. Although the agricultural usage of organochlorine insecticides, such as DDT and $\mathrm{HCH}$, have been banned in the Philippines, their pollution still remains in the aquatic environment. However, based on the results obtained in the present study and earlier published data for other geographical regions (Table 4), contamination by organochlorine pesticides in the Philippines is not of relatively serious concern.

\section{Heavy Metals}

Metal concentrations in the whole soft tissues of Perna viridis collected along the coastal waters of the Philippines are presented in Table 5. Among the metals analysed, the essential elements $\mathrm{Mn}$ and $\mathrm{Zn}$ were observed to be accumulated heavily by all the green mussels examined (Table 5). Green mussels from Jiabong, Samar (PHSMJB) had the highest $\mathrm{Mn}$ concentration $\left(112 \mu \mathrm{g} \mathrm{g}^{-1}\right.$ dry weight), while the highest $\mathrm{Zn}$ concentration ( $57.2 \mu \mathrm{g} \mathrm{g}^{-1}$ dry weight) was observed in green mussels from San Pedro Bay, Diit, Leyte (PHLTDT). In the case of $\mathrm{Zn}$, concentrations measured in green mussels from the Visayas region differed significantly from those collected from Luzon $(p<0.05$, Mann-Whitney test). Compared with other studies on metal accumulation in mussels, Mn concentration levels observed (27.4-112 $\mu \mathrm{g} \mathrm{g}^{-1}$ dry weight) in green mussels examined here were within the same range with levels detected in the whole soft tissues of the mussel Mytilus edulis from the Bay of Follonica, Italy, which ranged between $37-150 \mu \mathrm{g} \mathrm{g}^{-1}$ dry weight. ${ }^{33)}$ While $\mathrm{Zn}$ concentration levels (38.4-57.2 $\mu \mathrm{g} \mathrm{g}^{-1}$ dry weight) detected in green mussels analysed here were one order of magnitude lower than those of the blue mussel Mytulis edulis from the Bay of Follonica, Italy $\left(120-150 \mu \mathrm{g} \mathrm{g}^{-1}\right.$ dry weight ${ }^{33)}$ and from the East Coast of Kyushu Island, Japan $\left(118-360 \mu \mathrm{g} \mathrm{g}^{-1}\right.$ 
dry weight), ${ }^{34)}$ and likewise with the mussel Mytulis galloprovincialis from Algarvae Coast, South Italy (186-398 $\mu \mathrm{g} \mathrm{g}^{-1}$ dry weight). ${ }^{35)}$ Considerable accumulation of $\mathrm{Sr}$ was also noted, ranging from $19.0-77.0 \mu \mathrm{g} \mathrm{g}^{-1}$ dry weight, with relatively high levels in green mussels collected from Sapian Bay, Capiz (PHCZSP) and San Pedro Bay, Diit, Leyte (PHLTDT) (Table 5). In biological samples other than mussels, Sr data is available for commercial fish species from Manila Bay, Philippines, ${ }^{19)}$ which showed higher Sr accumulation ranging from $42.7-319 \mu \mathrm{g} \mathrm{g}^{-1}$ dry weight in their whole bodies compared to the levels found in mussels collected from Manila Bay and nearby coasts (PHMMMB, PHBTSL, PHLBA-2, PHCVBC-2) (Table 5).

Copper is another essential element in marine invertebrates that has been associated with numerous metalloenzymes and metalloprotiens, ${ }^{36}$ such as the $\mathrm{Cu}$-containing respiratory protein hemocyanin found in some mollusks and crustaceans. $\mathrm{Cu}$ concentrations ranged at 5.13-8.85 $\mu \mathrm{g} \mathrm{g}^{-1}$ dry weight, with small variations among the study sites. Similar range of $\mathrm{Cu}$ concentrations were observed in whole soft tissues of Mytulis edulis from the northern coast of Portugal (8.8-9.8 $\mu \mathrm{g} \mathrm{g}^{-1}$ dry weight), ${ }^{37)}$ and from Mersey Estuary, United Kingdom (8.1-12.3 $\mu \mathrm{g} \mathrm{g}^{-1}$ dry weight) ${ }^{38)} \mathrm{Rb}, \mathrm{V}, \mathrm{Li}$ and Co were accumulated to a lesser extent by the green mussels examined here, with similar levels of $\mathrm{V}$ and $\mathrm{Li}$ for both regions (Table 5). However, significant inter-regional differences $(p<0.05$, Mann-Whitney test) in concentrations of $\mathrm{Rb}$ and Co were found. On the other hand, low levels of $\mathrm{Ag}$ and $\mathrm{Cs}$ were measured in mussels from all sites and no significant inter-regional differences were observed. Similarly, low Ag and Cs levels were noted in fish species from Manila Bay, Philippines. ${ }^{19)}$

Generally, the order of concentration of highly toxic chemicals in green mussels examined was $\mathrm{Cd}>\mathrm{Hg}>\mathrm{Pb}$. The maximum Cd concentration of $0.960 \mu \mathrm{g} \mathrm{g}^{-1}$ dry weight was measured in mussels from Jiabong, Samar (PHSMJB), followed closely by those collected from Villareal, Samar (PHSMVR) $\left(0.760 \mu \mathrm{g} \mathrm{g}^{-1}\right.$ dry weight). Similar range of $\mathrm{Cd}$ concentrations were observed in Mytulis edulis from the northern coast of Portugal $\left(0.7-0.9 \mu \mathrm{g} \mathrm{g}^{-1}\right.$ dry weight ${ }^{37)}$ and from Urashiro coast, Kyushu, Japan $\left(0.92 \pm 0.08 \mu \mathrm{g} \mathrm{g}^{-1}\right.$ dry weight). ${ }^{34)}$ Mussels from Sapian Bay, Capiz (PHCZSP) exhibited the maximum level of $\mathrm{Hg}$ of $0.680 \mu \mathrm{g} \mathrm{g}^{-1}$ dry weight, while the highest $\mathrm{Pb}$ concentration of $0.280 \mu \mathrm{g} \mathrm{g}^{-1}$ dry weight was detected in mussels from Samal, Bataan (PHBTSL). However, Cd and Pb levels detected in the present study were much lower than the $\mathrm{Cd}\left(18.4 \pm 1.73 \mu \mathrm{g} \mathrm{g}^{-1}\right.$ dry weight) and $\mathrm{Pb}\left(122 \pm 17 \mu \mathrm{g} \mathrm{g}^{-1}\right.$ dry weight) levels in blue mussels from Saganoseki coast, Kyushu, Japan, believed to be one of the most polluted coastal areas to date. ${ }^{34)}$ Compared on a regional basis, it appears that the mean $\mathrm{Pb}$ and $\mathrm{Hg}$ concentrations are uniformly distributed, but $\mathrm{Cd}$ concentrations in mussels from the Visayas region was found to be significantly higher than those in mussels from the Luzon region $(p<0.05$, Mann-Whitney test).

Collectively, metal concentrations found suggest that the anthropogenic loading of $\mathrm{Hg}, \mathrm{Pb}$ and $\mathrm{Cd}$ to the coasts is relatively low. It may be inferred then that green mussels from these coastal waters are not adversely affected by these metal toxicants and pose no risk for human health.

To our knowledge, this is the first comprehensive report on the concentrations of butyltins, organochlorine compounds and heavy metals in soft tissues of green mussels in the Philippines.

Acknowledgments The authors wish to thank Dr. K. Kitazawa (UNESCO-IOC; present: Japan Marine Science and Technology Center) and Dr. G. Kullenberg (UNESCO-IOC), Mr. G. Paoletto and Dr. J. I. Uitto (The United Nations University, Japan), Prof. E. D. Goldberg (Chairman of the International Mussel Watch Committee), Prof. J. W. Farrington and Mr. B. W. Tripp (Woods Hole Institute of Oceanography, USA) for their encouragement and support. We would also like to acknowledge Mr. Arman Labenia (Department of Agriculture, Region VIII, Tacloban City, Philippines) and the students and staff of the Science Education Department, De La Salle University, Manila, Philippines for their help in the collection of samples. This research was supported by a Grant-In-Aid from the International Scientific Research programme of the Ministry of Education, Science and Culture of Japan (Project No. 09041163) and conducted on the duration of the Japan Society for the Promotion of Science (JSPS) Ronpaku Fellowship grant (DOST No. 9639) awarded to M.S. Prudente.

\section{References}

1) L. Cheong: Country report: Singapore: Bivalve culture in Asia and the Pacific, in "Proceedings of a Workshop held in Singapore" (ed. by F. B. Davy and M. Graham), International Development Research Centre, Ottawa, 1982, pp. 69-71.

2) E. D. Goldberg: Coastal zone space: prelude to conflict?, UNESCO, 1994, p. 138.

3) J. M. Vakily: The biology and culture of mussels of the genus Perna, ICLARM, Manila, 1989, p. 63.

4) W. G. Yap, A. L. Young, C. Orano and M. T. De Castro: Manual on mussel farming, in "Aquaculture Extension Manual" No. 6, Southeast Asian Development Center, Iloilo, Philippines, 1979, p. 17.

5) R. D. Guerrero, W. G. Yap, L. G. Handog, E. O. Tan, P. N. Torres, and M. C. Balgos: The Philippines recommends for mussels and oysters. PCARRD Tech. Bull., 26-A, 1-46 (1983).

6) A. L. Young and E. Serna: Country report: Philippines, in "Bivalve culture in Asia and the Pacific: proceedings of a workshop held in Singapore'" (ed. by F. B. Davy and M. Graham), International Development Research Centre, Ottawa, 1982, pp. 55-68.

7) S. Tanabe: International mussel watch in Asia-Pacific. Mar. Pollut. Bull., 28, 518 (1994).

8) K. Fent: Ecotoxicology of organotin compounds. Crit. Rev. Toxicol, , 26, 1-117 (1996).

9) C. Alzieu and M. Heral: Ecotoxicological effects of organotin compounds on oyster culture, in "Ecotoxicological Testing for the Marine Environment" (ed. by G. Persoone, E. Jaspers, and C. Claus), Vol. 2, State University, Belgium, 1984, pp. 187-195.

10) C. Alzieu and J. E. Portmann: The effect of tributyl tin on the culture of C. gigas and other species, in "Fifteenth Annual Shellfish Conference Proceedings", The Shellfish Association of Great Britain, London, 1984, pp. 87-104.

11) A. R. Beaumont and M. D. Budd: High mortality of the larvae of the common mussel at low concentrations of tributyltin. Mar. Pollut. Bull., 15, 402-405 (1984).

12) G. W. Bryan and P. E. Gibbs: Impact of low concentrations of tributyltin (TBT) on marine organisms: a review, in "Metal Ecotoxicology Concepts and Applications" (ed. by M. C. Newman and A. W. Mc Intosh), Lewis Publishers, plau 1991, pp. 323-361.

13) P. L. Layman: Marine coatings industry adopts new technology for shifting markets. Chem. Eng. News, May 1, 23-25 (1995).

14) A. M. Soto, K. L. Chung, and C. Sonnenschein: The pesticides endosulfan, toxaphene and dieldrin have estrogenic effects on human estrogen-sensitive cells. Environ. Health Perspect., 102, 380-383 (1994).

15) M. Zosa: Restricted Pesticides in the Philippines (pamphlet), Fertilizer and Pesticide Authority, Philippines, 1978.

16) J. Flavier: Memorandum Circular, Department of Health, Manila, 
Philippines, 1, 92 (1992).

17) H. R. Watling: Accumulation of seven metals by Crassostrea gigas, C. margaritacea, Perna perna and Chromytillus meridionalis. Bull. Environ. Contam. Toxicol., 30, 213-320 (1983).

18) M. S. Prudente, H. Ichihashi, and R. Tatsukawa: Heavy metal concentrations in sediments from Manila Bay, Philippines and inflowing rivers. Environ. Pollut., 86, 73-83 (1994).

19) M. S. Prudente, E. Y. Kim, S. Tanabe, and R. Tatsukawa: Metal levels in some commercial fish species from Manila Bay, Philippines. Mar. Pollut. Bull., 34, 671-674 (1997).

20) D. B. Lee, M. S. Prudente, S. Tanabe, and R. Tatsukawa: Organochlorine residues in soils and sediments from Manila and nearby provinces, Philippines. Toxicol. Environ. Chem., 60, 171181(1997).

21) M. S. Prudente, S. Tanabe, M. Watanabe, An. Subramanian, N. Miyazaki, P. Suarez and R. Tatsukawa: Organochlorine contamination in some odontoceti species from the North Pacific and Indian Ocean. Mar. Environ. Res., 44, 415-427 (1997).

22) S. Tanabe, M. Prudente, T. Mizuno, J. Hasegawa, H. Iwata and N. Miyazaki: Butyltin contamination in marine mammals from North pacific and Asian coastal waters. Environ. Sci. Tech., 32, 193-198 (1998).

23) S. Kan-atireklap, J. Sanguansin, M. Tabucanon, and $M$. Hungspreugs: Contamination by butyltin compounds and organochlorine residues in green mussel (Perna viridis, L.) from Thailand coastal waters. Environ. Pollut., 97, 79-89 (1997).

24) J. C. Duinker, D. E. Schulz and G. Petrict: Multidimensional gas chromatography with electron capture detection for the determination of toxic congeners in polychlorinated biphenyl mixtures. Anal. Chem., 60, 478-482 (1988).

25) K. Okamoto: In "Plasma Source Mass Spectrometry", (ed. by H. Kawaguchi and T. Nakahara), IBSN, Tokyo, 1994, pp. 128-147.

26) H. Akagi and H. Nishimura: Speciation of mercury in the environment, in "Advances in Mercury Toxicology" (ed. by T. Suzuki, N. Imura, and T. W. Clarkson), Plenum Press, New York, 1991, pp. 53-76.
27) R. J. Maguire, Y. K. Chau, G. A. Bengert, E. J. Hale, P. T. S. Wong, and O. Kramar: Occurrence of organotin compounds in Ontario lakes and rivers. Environ. Sci. Tech., 16, 698-702 (1982).

28) D. S. Page, C. C. Ozbal, and M. E. Lanphear: Concentration of butyltin species in sediments associated with shipyard activity. Environ. Pollut., 91, 237-243 (1996).

29) T. Horiguchi, H. Shiraishi, A. Otsuki, and S. Hashimoto: Imposex and organotin compounds in Thais clavigera and $T$. bronni in Japan. J. Mar. Biol. Assoc., U.K. 74, 651-669 (1994).

30) R. F. Lee: Metabolism of tributyltin by marine animals and possible linkages to effects. Mar. Environ. Res., 32, 29-35 (1991).

31) R. F. Lee: Metabolism of tributyltin by aquatic organisms, in "Organotin" (ed. by M. Champ and P. F. Seligman), Chapman and Hall, London, 1995, pp. 369-382.

32) K. Kannan, S. Tanabe, H. Iwata, and R. Tatsukawa: Butyltins in muscle and liver of fish collected from certain Asian and Oceanian countries. Environ. Pollut., 90, 279-290 (1995).

33) R. Bargagli, F. Baldi, and C. Leonzio: Trace metal assessment in sediment, molluscs and leaves in the Bay of Follonica (Italy). Mar. Environ. Res., 16, 281-300 (1985).

34) P. Szefer, K. Ikuta, K. Kushiyama, K. Szefer, K. Frelek, and J. Geldon: Distribution and association of trace metals in soft tissue and byssus of Mytulis edulis from the east coast of Kyushu Island, Japan. Arch. Environ. Contam. Toxicol., 32, 184-190 (1997).

35) M. J. Bebianno and M. Machado: Concentrations of metals and metallothioneins in Mytilus galloprovincialis along the south coast of Portugal. Mar. Pollut. Bull., 34, 666-671 (1997).

36) D. R. Thompson: Metal levels in marine invertebrates, in "Heavy Metals in the Marine Environment" (ed. by R. W. Furness and P. S. Rainbow), CRC Press Inc., Boca Raton, 1990, pp. 143-182.

37) E. I. Hamilton: Metals in Mytulis edulis from the northern coast of Portugal. Mar. Pollut. Bull., 22, 249-253 (1991).

38) G. Bryan, W. Langston, L. Hummerstone, and G. Burt: A guide to the assessment of heavy metal contamination in estuaries using biological indicators. Mar. Biol. Assoc., UK (Occasional Publication), 4, 92 (1985). 